\title{
The Efficacy of Strategies-based Listening Instruction (SBLI)
}

\author{
Yan Liu \\ Yuncheng University, Yuncheng, Shanxi, 044000
}

Keywords: Strategies-based Listening Instruction; strategy awareness; comprehension awareness

\begin{abstract}
For learners with different proficiency, as well as with different ages and nationalities, any model of strategies-based instruction approach can improve listeners' strategy awareness and comprehension awareness. Besides, the effects of strategies-based instruction on listening performance improvement were also reported in related studies. In spite of the desiring results of applying SBLI, some caveats will be worth aware of for future studies.
\end{abstract}

\section{Introduction}

In English as a second language (ESL) learning and teaching, listening plays a key role which lies in that listening provides information or input for learners. It facilitates building up the related information essential for language using (Nation \& Newton, 2009; Rost, 1994). "When this knowledge is built up the learner can begin to speak" (Nation \& Newton, 2009, p.38). Such input from listening is of crucial importance in ESL learning. Thus, listening comprehension is "regarded as one of the most significant macro-skills in second language acquisition theory, research, pedagogy, and other various settings such as work, travel and communication" (Rahimirad \& Shams, 2014, p.163). However, more often than not, scholars in pedagogy hold the view that listening comprehension is mostly an overlooked skill in ESL acquisition (Rahimirad \& Shams, 2014; Vandergrift, 2004). Only recently, has listening comprehension gained more attention in the ESL literature than it has received in the past. "Now listening is recognized as an active process, critical to L2 acquisition and deserving of systematic development as a skill in its own right" (Siegel, 2013; Vandergrift, 2004, p.3).

Researchers realized that many ESL learners view listening as the most difficult skill of the four macro language skills, including reading, writing, speaking and listening (e.g. Renandya \& Farrell, 2011; Vandergrift, 2004). The difficulties reported by L2 learners lie in different perspectives, such as text factors, processing factors, task factors and learner factors (Goh, 2000; Hasan, 2000; Thompson \& Rubin, 1996).

In order to address the difficulties lying in L2 listening, listening methodologists such as Mandelsohn (1994) and Siegel (2011) have recommended explicit listening strategies teaching. "Mendelsohn was among the first to describe in detail the specific workings of a strategy-based approach to the teaching of L2 listening" (Siegel, 2013, p.3). Mendelsohn (1994) states that it "sees the objective... as being to train students how to listen, by making learners aware of the strategies that they use, and training them in the use of additional strategies that will assist them in tackling the listening task" (p.37). Besides, strategy-based listening instruction needs to give attention to not only bottom-up processes but also top-down ones (Siegel, 2013). Furthermore, it is also essential to combine cognitive and metacognitive strategies for effective SBLI (Siegel, 2013; Vandergrift, 2003).

\section{The SBLI}

\subsection{Strategy}

The literature does not provide one unanimously agreed definition of learner strategies (Siegel, 2003; Graham and Macaro, 2008). Macaro (2006, p.328) argued that the "essential features of a strategy are conscious mental activity, employed in the pursuit of a goal within a learning situation, and transferable to other situations or tasks". Cognitive, metacognitive and social-affective 
strategies are the three types of learning strategies which have also been applied in listening instruction (Chamot, 1993; Goh, 2000; Siegel, 2013). Cognitive strategies are unconscious interactions with the listening materials, including inferencing, prediction, visualization, summarizing and note-taking. Metacognitive strategies are used to plan and decide which listening strategies are best served in a particular situation, like directed attention, selective attention, planning, monitoring and evaluation. Social affective strategies include interacting with peers or management of affection to facilitate learning, such as cooperation with peers, asking questions and controlling stress (Goh, 2000; Graham et al., 2011; Mendelsohn, 1994).

\subsection{Top-down and bottom-up approaches}

The top-down and the bottom-up approaches complement each other during the listening process (Graham \& Macaro, 2008; Siegel, 2013). In the top-down approach, "listeners process the context of the listening situation using their existing knowledge and build up expectations about what they will likely hear” (Siegel, 2013, p.3). The bottom-up processes from the sounds, then words, phrases, combined to form sentences and so on (Siegel, 2013).

\subsection{SBLI model}

Although programs have similarities and differences as for which strategies are taught and the amounts of support provided by teachers during the structured practice phase. However, in terms of how a SBLI program might proceed, the studies have adopted a model which can be summarized as follows:

- consciousness raising, in which students reflect on the nature of learning and on the strategies they use at present;

- modeling of selected strategies by the teacher;

- guided and structured practices of the new strategies in the context of normal class activities, with gradually fewer reminders to use appropriate strategies;

- action planning, goal setting and evaluation, "whereby learners identify problem areas, select strategies that might help remedy them and evaluate their success" (Graham and Macaro, 2008, p.753).

- expansion, whereby listeners are encouraged to apply the strategies in their other classes or learning contexts (Carrier, 2003; Mendelsohn, 1994)

\section{The controversial efficacy of SBLI}

It is argued that promoting the use and development of listening strategies through SBLI facilitates more efficient, effective and autonomous listeners in literature on L2 listening pedagogy (e.g. Thompson \& Rubin, 1996; Vandergrift, 2002, 2004).

However, there are a number of concerns over SBLI. For instance, Renandya (2012) has argued that strategy instruction places extra demands on teachers that many teachers will find it difficult to carry out. Strategy training which is not the same as language learning cannot be a substitute for basic language teaching (Renandya, 2012). Researchers also hold the idea that learners, especially lower proficiency learners, do not have enough cognitive capacity to activate the taught strategies consciously and listen simultaneously (Renandya, 2012). Besides, Chen (2005) analyzed learners' reporting that a range of "barriers encountered during a program of instruction classified as affective, habitudinal, information-processing, English proficiency, strategic, belief and material, which may inhibit the learning of listening strategies” (Cross, 2009, P.154).

In view of the pedagogical and theoretical arguments, it is high time to review the associated empirical research conducted to find evidence to support or refute the efficacy of SBLI.

\section{Literature review about the efficacy of SBLI}

\subsection{Learners' perceptions towards SBLI}

Students' perceptions on SBLI can offer “insight on any resulting internal cognitive and 
metacognitive changes stimulated by SBLI and offer viewpoints as to the effectiveness of a SBLI" (Siegel, 2013, p.4). In the meantime, students' perceptions of SBLI serve to facilitate teachers better understanding how to best guide learners in improving their L2 listening comprehension skills (Graham, 2006; Siegel, 2013).

By conducting questionnaire survey and semi-structured interview, Graham (2006) investigates into the perceptions towards L2 listening comprehension held by high school French learners in UK and how they view the reasons behind their success or lack of it in the listening comprehension skill. In the study, "many learners regard themselves as less successful in listening than in other language areas” (ibid. p.78) and most learners regards the difficulties lying in their own low listening ability and in the difficulty of the listening tasks. Graham (2006, p.178) argued students "displayed little insight into what strategies might be appropriate for listening and the need to monitor and evaluate any strategies that they did employ". Thus, there is a need for teachers to address the 'how' of listening, which includes bottom-up and top-down processes, and the implement explicit strategy instruction, such as meta-cognitive strategies to help students better plan, monitor and evaluate their listening process in order to improve students' listening abilities.

Bidabadi and Yamat (2013) also find the same need to implement meta-cognitive strategies in listening after exploring Iranian tertiary-lever female learners' perceptions toward the use of meta-cognitive processes. They concluded that the learners use "directed knowledge strategies more frequently followed by planning and evaluating, problem-solving, and personal knowledge strategies respectively" (ibid, p.39). And learners believe that the strategies are important for them to become good L2 listeners. Thus, the researchers reported "the explicit meta-cognitive strategy training would contribute to the improvement of the EFL learners in their listening skills and comprehension" (ibid. p.39).

Thus, it appears learners' perception necessitates the SBLI to enhance their listening comprehension skills.

\subsection{In the absence of explicit SBLI}

Graham, Santos, and Vanderplank (2007) examines the relationship between two lower-intermediate L2 secondary school French learners' listening proficiency and strategic behavior and to discover how this relationship develops over 6 months in the absence of explicit SBLI. The researchers concluded that there are strategy differences between the two learners, a high scorer and a low scorer on the both tests. And the two learners remained consistent strategy use over the six month period. The study indicates that "strategy use is high individualized" and no matter what strategies listeners use, they need to know "how to use them effectively and appropriately to deal with task demands” (ibid. pp. 66-67). Thus, teachers should give SBLI to guide students to use the strategies effectively and appropriately to deal with the different task demands.

Besides, Graham, et al (2011) conduct another research to investigate the relationship between changes in 15 lower-intermediate French learners' strategy use and their listening performance in the absence of SBLI. Through recall protocols to test listening proficiency and individual listening activities to elicit strategies students use at the beginning and after 6 months, the researchers "underlined more firmly the highly individual nature of strategy use and strategy development, and the relative lack of strategy development in the absence of strategy instruction" (ibid. p.450). They also emphasize "the importance of students developing a sense of being 'in charge' of the listening process, including knowing how and when to use which strategies” (ibid. p.451).

To sum up, although the strategy use is highly individualized, there is a need for teachers to address SBLI to improve students' strategy development in order to improve learners' listening comprehension skills in the end.

\subsection{Students' improvement as a result of SBLI}

\subsubsection{Process-based listening instruction for primary school students}

To benefit learners understanding mental and emotional processes involved in their listening learning, teachers can guide listeners in exploring important aspects of the listening process. 
Teaching explicitly the listening process and develops learners' knowledge about the listening process is referred to as 'metacognitive instruction' by Goh and Taib (2006).

Goh and Taib (2006) conducted a study with 10 primary school students in Singapore to identify the metacognitive knowledge about listening in English of primary school pupils and to investigate the usefulness of process-based activities for teaching listening to the students. The study claims that primary school pupils can benefit from explicit strategy instruction in spite of the fact that they need more guidance from their teachers to mediate their perceptions towards strategies and task demands.

Vandergrift (2002) also conducted such a process-based listening instruction to primary school Core French $^{*}$ students. Results suggest that it makes students sensitive to the processes underlying L2 listening comprehension and tapped their metacognitive knowledge. According to Vandergrift (2002), the emphasis on the process of listening and comprehension can potentially foster students learning autonomy and achieve greater success in language learning. In addition, teaching for metacognition provides "beginning-level language learners with the knowledge and tools for meaningful transfer of learning so that they know how to listen to and understand authentic texts outside of the classroom" (ibid. p.573).

\subsubsection{SBLI for high school students}

Carrier (2003) designs a 15-session targeted SBLI for 7 American high school ESL students to explore the effect of listening strategy instruction on students' listening comprehension of oral academic content material. It shows that SBLI helped students improve their discrete listening ability and their abilities to listen to videos and take notes which will further develop their "listening comprehension of oral academic content material that they will most likely encounter in their academic content class" (ibid, p.398).

Graham and Macaro (2008) also selected high school-level (year 12) students to be the target population to test the effectiveness of the strategy instruction program with additional materials for raising awareness of bottom-up processes and reflection. The high scaffolding group receives written personalized feedback on strategies they might have used to underline the connection between strategies and outcomes. Overall, the SBLI program had a positive effect on listening performance. And the strategy instruction with "feedback that focuses on the link between strategy use and successful listening can have a positive impact on both listening performance and students' self-efficacy for listening” (ibid. p.772).

Another SBLI in developing secondary school students' listening comprehension skills conducted by Admin, Admin and Aly (2011, p.1) found that "the experimental group achieved more gains in their EFL listening comprehension skill and each sub-skill (e.g. listening for detailed information, listening for prediction) due to using the SBLI".

\subsubsection{SBLI for university-level students}

The first longitudinal, classroom-based SBLI experiment that demonstrates the positive effect of SBLI is carried out by Thompson and Rubin (1996). They taught university-level learners of Russians metacognitive strategy, cognitive strategy and special cognitive strategy for the genre like drama, interview and news. They confirmed that strategy instruction resulted in improved performance on the video test.

By integrating a process approach into regular listening exercises, Vandergrift (2003) involved 41 university FSL students to experiment with tasks that can teach students the listening process and to determine the effectiveness of the tasks in facilitating listening comprehension. "It appears that systematic consciousness-raising did lead these students to become more sensitive to the process of listening and to develop matacognitive knowledge about L2 listening” (ibid. p. 438). And the effects of the instruction on student awareness and motivation in this study have been noted. However, "the effects on listening achievement need to be empirically investigated” (ibid. p.438).

Vandergrift and Tafaghodtari (2010) did an empirical investigation of a pedagogical approach to L2 listening for 106 university-level FSL students that focused on the long-term development of strategic listening. The subjects were given listening test at the beginning and the end of the study 
and their change in metacognitive knowledge about listening was measured using the MALQ (Metacognitive Awareness Listening Questionaire) (Vandergrift, et al. 2006) at the beginning, middle and end points of the study, immediately after a listening activity. The approach which sensitizes listeners to the listening processes can improve L2 listening success, especially benefit the less skilled listeners more.

Another SBLI was also carried out by Siegel (2013) to guide English learners at a university in Japan, in which listening strategies were named, demonstrated, explicitly taught and practiced. During the instruction, students were well-informed of the strategies and the possible benefits of the strategies when they are used in academic and real world listening. After the instruction finished, by investigating into perceptions of SBLI held by learners through questionnaire survey and group interviews, the researcher reported that these learners show positive perceptions of the listening strategy instruction framework. "Many students reported that their listening abilities improved as a result of the course as a whole and specific aspects of the SBLI were identified as useful elements for listening pedagogy” (Siegel, 2013, p.12).

In addition, Rahimirad and Shams (2014) utilize Vandergrift and Tafaghodtari's (2010) approach to investigate the effect of activating metacognitive strategies on the 50 university-level Iran students' EFL listening performance. It concludes that "metacognitive strategy instruction can significantly improve listening performance among EFL students and raise their metacognitive awareness of the processes involved during listening task" (ibid. p.171).

\subsubsection{SBLI for advanced-level adults}

By using the pedagogical cycle encompassing pre-listening preparation, monitor and evaluation of performance, Cross (2009) investigates the impact of SBLI on advanced-level EFL Japanese adult learners' comprehension of BBC news videotexts. It proves that systematically leading language learners through the listening activities encourages the adult learners to develop greater awareness of the metacognitive processes involved in listening comprehension.

\section{Conclusion}

In conclusion, for learners with different proficiency, as well as with different ages and nationalities, any model of strategies-based instruction (e.g. process-based strategy instruction, the pedagogical cycle used by Vandergrift (2003), the metacognitive, process-based approach based on Vandergrift (2004), or the pedagogical cycle model proposed by Vandergrift and Tafaghodtari (2010) approach can improve listeners' strategy awareness and comprehension awareness. That is, the listeners become more sensitive to the process of listening and to develop metacognitive knowledge about L2 listening (Vandergrift, 2002; Vandergrift, 2003; Graham and Macaro, 2008; Cross, 2009; Vandergrift and Tafaghodtari, 2010; Siegel, 2013; Rahimirad and Shams, 2014). Besides, the effects of strategies-based instruction on listening performance improvement also reported in studies like Carrier (2003); Goh and Taib (2006), Graham and Macaro (2008), Vandergrift and Tafaghodtari (2010), Amin, et al. (2011), Badabadi and Yamat (2013), Siegel (2013) and Rahimirad and Shams (2014).

In spite of the desiring results of applying SBLI, some caveats will be worth aware of for future research.

- In order to design proper SBLI for learners, the first step will be identifying learners' learning styles and strategies they are using.

- During SBLI, students themselves should have the right to choose the appropriate strategies they want to apply not the strategies teacher imposed on them.

- SBLI is not a pre-determined readymade package waiting for the teachers to be implemented in the classrooms. Thus, both teacher and students need to reflect on what they have covered in the classroom, the problems encountered, and so on.

- Teachers can give listeners feedback about the link between strategy use and successful listening which can have a positive impact on both listening performance and students' self-efficacy for listening (Graham and Macaro, 2008). 
- Instruction should provide learners with the knowledge and tools necessary for the meaningful transfer of listening so that they know how to listen to and understand authentic texts inside and outside of the classroom (Vandergrift and Tafaghodtari, 2010).

(2973 words)

Note

*Core French is a second language program intended to enable students to communicate with some very basic communication skills in French

\section{Acknowledgements}

1) Education and Science Planning Project of Shanxi Province----A Comparative Study on the Education of Chinese and American Foreign Language Teachers (GH-16093)

2) Research Project of Yuncheng University ----A Comparative Study on Chinese and Foreign Teachers’ Discourse in English Reading Class (XK-2016003)

\section{References}

[1] Amin, I. A. R., Amin, M. M., \& Aly, M. A. S. (2011). The Effectiveness of Using an Explicit Language Learning Strategy-Based Instruction in Developing Secondary School Students' EFL Listening Comprehension Skills. ERIC.

[2] Bidabadi, F. S., \& Yamat, H. (2013). EFL Learners’ Perceptions towards Meta-Cognitive Strategy Use in English Language Listening. GEMA Online ${ }^{\circledR}$ Journal of Language Studies, 13(3), 31-43.

[3] Carrier, K. A. (2003). Improving high school English language learners' second language listening through strategy instruction. Bilingual Research Journal, 27(3), 383-408.

[4] Chamot, A. U. (1993). Student responses to learning strategy instruction in the foreign language classroom. Foreign Language Annals, 26(3), 308-320.

[5] Cross, J. (2009). Effects of listening strategy instruction on news videotext comprehension. Language Teaching Research, 13(2), 151-176.

[6] Goh, C. (2000). A cognitive perspective on language learners' listening comprehension problems. System, 28(1), 55-75.

[7] Goh, C., \& Taib, Y. (2006). Metacognitive instruction in listening for young learners. ELT journal, 60(3), 222-232.

[8] Graham, S. (2006). Listening comprehension: The learners’ perspective. System, 34(2), 165-182.

[9] Graham, S., \& Macaro, E. (2008). Strategy instruction in listening for lower-intermediate learners of French. Language learning, 58(4), 747-783.

[10] Graham, S., Santos, D., \& Vanderplank, R. (2007). Listening comprehension and strategy use: A longitudinal exploration. System, 36(1), 52-68.

[11] Graham, S., Santos, D., \& Vanderplank, R. (2011). Exploring the relationship between listening development and strategy use. Language Teaching Research, 15(4), 435-456.

[12] Hasan, A. S. (2000). Learners' perceptions of listening comprehension problems. Language Culture and Curriculum, 13(2), 137-153.

[13] Macaro, E. (2006). Strategies for language learning and for language use: Revising the theoretical framework. The Modern Language Journal, 90(3), 320-337.

[14] Mendelsohn, D. J. (1994). Learning to listen: A strategy-based approach for the second-language learner. San Diego, CA: Dominie Press.

[15] Nation, I. S. P., \& Newton, J. (2009). Teaching ESL/EFL listening and speaking. New York: 
Routledge.

[16] Renandya, W. A. (2012). Five reasons why listening strategy instruction might not work with lower proficiency learners. English Language Teaching World Online, 3.

[17] Rahimirad, M., \& Shams, M. R. (2014). The Effect of Activating Metacognitive Strategies on the Listening Performance and Metacognitive Awareness of EFL Students. International Journal of Listening, 28(3), 162-176.

[18] Renandya, W. A., \& Farrell, T. S. (2011). 'Teacher, the tape is too fast!' Extensive listening in ELT. ELT journal, 65 (1), 52-59.

[19] Rost, M. (1994). Introducing listening. London, England: Penguin Publishers.

[20] Siegel, J. (2011). Thoughts on L2 listening pedagogy. ELT journal, 65(3), 318-321.

[21] Siegel, J. (2013). Second language learners' perceptions of listening strategy instruction. Innovation in Language Learning and Teaching, 7(1), 1-18.

[22] Thompson, I., \& Rubin, J. (1996). Can strategy instruction improve listening comprehension? Foreign Language Annals, 29(3), 331-342.

[23] Vandergrift, L. (2002). 'It was nice to see that our predictions were right': developing metacognition in L2 listening comprehension. Canadian Modern Language Review/La revue canadienne des langues vivantes, 58(4), 555-575.

[24] Vandergrift, L. (2003). From Prediction Through Reflection: Guiding Students: Through the Process of L2 Listening. Canadian Modern Language Review/La Revue canadienne des langues vivantes, 59(3), 425-440.

[25] Vandergrift, L. (2004). Listening to learn or learning to listen? Annual Review of Applied Linguistics, 24, 3-25.

[26] Vandergrift, L., \& Tafaghodtari, M. H. (2010). Teaching L2 learners how to listen does make a difference: An empirical study. Language Learning, 60(2), 470-497. 